\title{
(2) OPEN ACCESS \\ Straw cigarette branding: misleading descriptors and a new Marlboro man
}

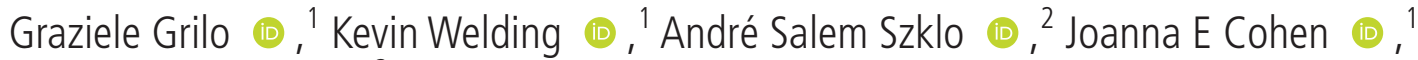 \\ Katherine Clegg Smith ${ }^{3}$
}

- Additional supplemental material is published online only. To view, please visit the journal online (http://dx.doi. org/10.1136/tobaccocontrol2021-056983).

${ }^{1}$ Institute for Global Tobacco Control, Johns Hopkins University Bloomberg School of Public Health, Baltimore, Maryland, USA

${ }^{2}$ Population Research Unit, National Cancer Institute, Rio de Janeiro, Brazil

${ }^{3}$ Department of Health, Behavior and Society, Johns Hopkins University Bloomberg Schoo of Public Health, Baltimore, Maryland, USA

\section{Correspondence to}

Graziele Grilo, Institute for Global Tobacco Control, Johns Hopkins University Bloomberg School of Public Health, Baltimore, MD 21205, USA; ggrilo@jhu.edu

Received 13 August 2021 Accepted 1 November 2021
D) Check for updates

(C) Author(s) (or their employer(s)) 2021. Re-use permitted under CC BY-NC. No commercial re-use. See rights and permissions. Published by BMJ.

To cite: Grilo G, Welding K, Szklo AS, et al. Tob Control Epub ahead of print: [please include Day Month Year]. doi:10.1136/

tobaccocontrol-2021-056983

\section{ABSTRACT \\ Background Straw cigarettes are hand-rolled tobacco} in a corn straw, common in Brazil and believed to be less harmful by consumers. Traditionally consumed in rural areas and by men, a recent increase in use among young people in urban areas was observed. This study assessed marketing appeals of straw cigarette packaging in Brazil. Methods Following a systematic protocol, unique straw cigarette packs were purchased in 2013, 2016 and 2019 from three cities: Manaus, Salvador and São Paulo. Packs were double-coded for the absence/presence of marketing appeals (ie, luxury/quality, masculinity, classic/ timeless, flavours and less harm).

Results The number of unique straw cigarette packs purchased as part of the overall sample increased in the most recent collection: $2.3 \%(n=3), 1.3 \%(n=2)$ and $15.5 \%(n=27)$ in 2013, 2016 and 2019, respectively. Across the years, all packs presented luxury/quality elements (eg, images of crests); $93.8 \%(n=30)$ included the word 'artisanal'. Masculine appeal (eg, images of men) was present on $56.3 \%(n=18)$ of packs. Almost half had classic/timeless elements, including the words 'tradition'/'original'. In 2019, 59.3\% ( $n=16)$ of the packs were flavoured compared with none in previous years. Over a quarter of all packs presented a less harm appeal (eg, 'smooth').

Conclusion We identified an increase in availability of unique straw cigarette packs, strong branding and use of misleading descriptors on the packs. The adoption of plain packaging and the implementation of Brazil's additive ban could help to reduce the appeal of straw cigarettes and curb the current increase in use among youth.

\section{INTRODUCTION}

Straw cigarettes are hand-rolled unfiltered cigarettes, common in Brazil, in which tobacco is rolled in a corn husk that resembles a straw; overall, straw cigarette sticks are longer and thinner than regular cigarettes. Similar to other tobacco products that might not be machine manufactured, such as bidis in India and some kreteks in Indonesia, ${ }^{1}$ straw cigarettes are often seen as more natural and less harmful than cigarettes by consumers. ${ }^{2}$ However, studies among mice found that exposure to straw cigarette smoke causes damage similar to any other cigarette. $^{2-4}$

Beyond health dangers, straw cigarette production also raises socioeconomic concerns at the national level. In 2019, the Brazilian Federal Police exposed several cases of tax evasion involving straw cigarette companies that had resulted in a government loss of $\mathrm{R} \$ 100$ million. ${ }^{5}$ The investigation concluded that many straw cigarette companies have not registered their products with Anvisa (the Brazilian Health Regulatory Agency) or are not registered as tobacco producers. ${ }^{6}$ It has been reported that the supply chain relies on informal jobs that do not follow Brazilian labour laws, including child labour. ${ }^{7}$

Recent media coverage indicates an increased interest and use of straw cigarettes among youth in urban areas. ${ }^{8} 9$ Comparisons of data from the 2019 National Health Survey (PNS, in Portuguese) with the 2013 PNS data show a statistically significant increase in use observed among young adults aged $18-24$ years. In $2019,5.7 \%$ of men and $1.1 \%$ women reported usage (compared with $3.4 \%$ and $0.7 \%$ in 2013). ${ }^{10}$ The urban-rural comparison is $3.2 \%$ in urban areas in 2019 (2.0\% in 2013) and $4.5 \%$ in rural areas (compared with $2.2 \%$ in 2013). ${ }^{10}$ The same survey found that $9.9 \%$ of the Brazilian population over 18 years old smoked manufactured cigarettes. ${ }^{10}$

Brazilian legislation requires that all tobacco packs display a pictorial health warning label covering $100 \%$ of the back, and a text warning covering $30 \%$ of the front and $75 \%$ of one lateral side. ${ }^{11}$ Additionally, the use of misleading descriptors on packaging that might create the impression that tobacco products are less harmful (eg, mild and smooth) is prohibited. ${ }^{11}$ Despite these measures, previous research has shown that cigarette packs in Brazil have elaborate designs that, in many cases, communicate the addition of flavour. ${ }^{12}$ Studies among Brazilian women found that branded packs $^{13}$ and those communicating the addition of flavors ${ }^{14}$ increased positive perceptions of tobacco. However, to the best of our knowledge, studies have not assessed branding on tobacco products beyond regular cigarettes in Brazil; this study helps to fill this gap by assessing the marketing appeals of straw cigarette packs and comparing their frequency of appeals with those of cigarettes.

\section{METHODS}

The Tobacco Pack Surveillance System (TPackSS) systematically collects unique tobacco products sold in low/middle-income countries with the greatest number of smokers, including Brazil, with new data collection following the implementation of new health warning label policies. ${ }^{15}$ Unique tobacco products are defined as any pack with at least one difference in an exterior pack feature, such as stick count, size and colours. Cigarette and straw cigarette packs were collected in 2013, 2016 and 2019 in three Brazilian cities chosen among the top 10 
most populated cities to represent cultural and geographical diversity: Manaus, Salvador and São Paulo. Tobacco products were purchased across four types of vendors: eating establishments (such as bakeries and bars), supermarkets, convenience stores and mini markets. Data collection methods are reported elsewhere. $^{15}$

During data collection in 2019, we observed an increase in number of straw cigarettes in our sample and unique marketing appeals on straw cigarette packaging. We conducted an observational thematic review of all straw cigarette packs, in which the following appeals stood out: masculinity, classic/timeless, quality, flavour and less harm. Packs were then double-coded by independent coders based on an established TPackSS codebook $^{16}$ for the presence of imagery and/or lexical marketing appeals including luxury/quality elements (eg, 'gold', 'export', crowns), masculinity (eg, male images, cars, sports), classic/ timeless elements (eg, 'original', 'established', crests), flavours and less harm (eg, 'mild', 'smooth'). Coders were also able to describe any other appeal using a write-in response. A third coder resolved any discrepancies between coders. The prevalence and bias adjusted kappa statistic had an average of 0.864 (range: 0.690-0.995) across all variables and years. Descriptive analyses were conducted using Stata V.14. While the primary goal of this analysis was to quantify the frequency of marketing appeals on straw cigarette packs per year and pooled, we also sought to compare the pooled frequencies of those appeals with the ones on cigarette packaging. Given that straw cigarettes might not be a widely known product, the comparison with regular cigarettes helps to put the results into perspective. We compared appeal categories using chi-squared and Fisher's exact tests.

\section{RESULTS}

The quantity of unique straw cigarette packs collected considerably increased between the first and last data collection: they comprised 2.3\% $(n=3), 1.3 \%(n=2)$ and $15.5 \%(n=27)$ of the total unique tobacco products purchased in 2013, 2016 and 2019, respectively. While in 2013 and 2016, unique straw cigarette packs were only found in São Paulo $(n=2$ and $n=1$, respectively) and Salvador ( $\mathrm{n}=1$ per year), in 2019 unique straw cigarette packs were collected in São Paulo $(n=5)$, Salvador $(n=12)$ and Manaus $(n=10)$.

All unique straw cigarette packs across the 3 years had luxury/ quality elements, such as images of a crown, laurel wreath, crest and mentions of different editions (eg, gold). The vast majority of packs $(93.8 \%, \mathrm{n}=30)$ were described by the word 'artesanal' or 'artesanais' (artisanal). Masculinity appeals were consistently used across the years $(56.3 \%, \mathrm{n}=18 ; 2$ out of 3 packs in 2013, both packs in 2016 and 14 (51.9\%) in 2019), which included images of men (eg, cowboys, men playing guitar and smoking) and references to auto racing (Formula 1, checked flags). In addition, almost half $(46.9 \%, \mathrm{n}=15 ; 1$ out of 3 packs in 2013, neither pack in 2016 and 14 (51.9\%) in 2019) had classic/ timeless elements on the pack, including the term 'traditional' (18.8\%, $\mathrm{n}=6$; one out of three packs in 2013, neither pack in 2016 and five $(18.5 \%)$ in 2019) and the terms 'original' and/ or 'signature' (15.6\%, n=5; only observed among 2019 packs) (figure 1).

While we did not observe any packs with flavours in 2013 and $2016,59.3 \%(n=16)$ of the unique straw cigarette packs were flavoured in 2019. Flavours included menthol, coconut, cinnamon, chocolate and grape. In addition, $31.3 \%(n=10)$ of

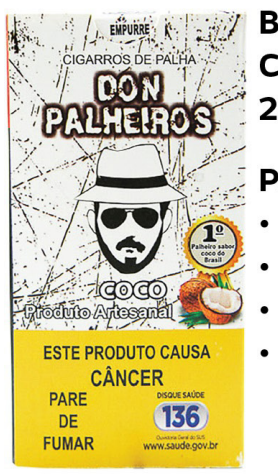

\author{
Brand: Don Palheiros \\ City/Year: Salvador, \\ 2019
}

Pack coded for: luxury/quality "artesanal" masculinity flavor (coconut)

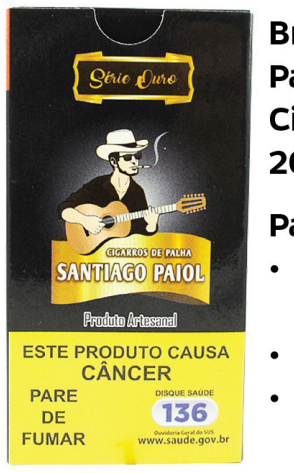

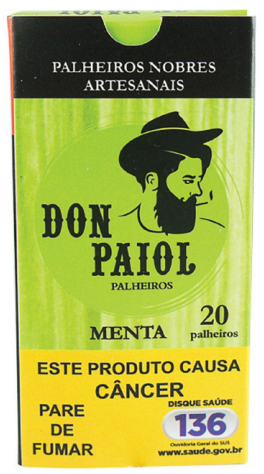

Brand: Don Paiol
City/Year: Salvado
2019
Pack coded for:
- Iuxury/quality
- "artesanal"
- masculinity
- quality (noble)
- flavor (mint)

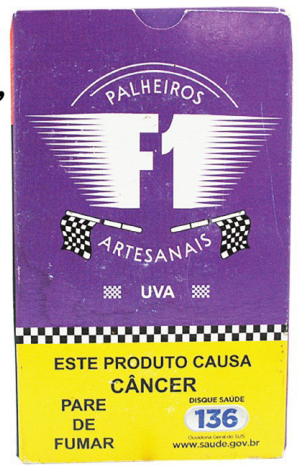

Brand: F1

City/Year: Manaus, 2019

Pack coded for:

- Iuxury/quality

- “artesanal"

masculinity

flavor (grape)

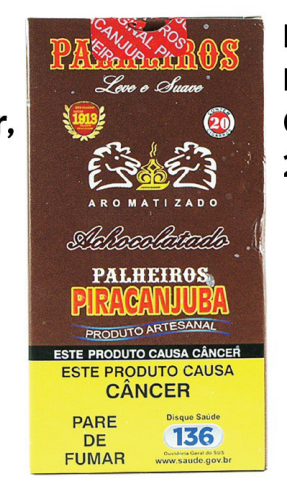

Brand: Imperio City/Year: Manaus, 2019

Example of a straw cigarette stick, menthol flavored

Figure 1 Examples of straw cigarette packs and a straw cigarette stick. 
the packs presented less harm elements, such as the use of the terms 'light' and 'smooth' ( 2 out of 3 packs in 2013, neither of the 2016 packs, and 8 (29.6\%) in 2019).

Online supplemental table 1 presents a comparison of the marketing appeals between straw cigarettes and cigarettes across all years. Apart from classic/timeless elements and specifically the use of the terms 'original'/'signature', the various marketing appeals found on straw cigarettes were significantly more prevalent than on cigarette packs.

\section{DISCUSSION}

This is the first study to assess marketing appeals on straw cigarette packs in Brazil. In addition to the increase in availability of unique straw cigarette packs across the years, we found most packs contained the marketing appeals of luxury/quality including the term 'artesanal', masculinity, classic/timeless and flavours, and over a quarter contained less harm elements. Overall, straw cigarette packs employed more of these packaging appeals than cigarettes packs, suggesting a different marketing approach. Notwithstanding, these comparisons are limited by the sampling method and the small sample size of straw cigarettes compared with cigarettes.

The increase in the proportion of packs with flavours is of particular note, especially when taking into account the rise in use of straw cigarettes among those aged 18-24 years old. ${ }^{10} \mathrm{~A}$ similar increase has been observed in the proportion of flavour capsule cigarettes $(10 \%$ vs $16 \%$ in 2013 and 2019, respectively). ${ }^{12}$ Latin America is a prosperous market for flavoured cigarettes, which are particularly appealing to youth. ${ }^{17}$ In 2012 , Anvisa passed a comprehensive resolution prohibiting the addition of additives to tobacco products that enhance flavour and taste $^{18}$; however, the resolution has yet to be implemented due to litigation by the tobacco industry.

Despite prohibiting misleading descriptors on packaging that might create the impression that certain tobacco products are less harmful, ${ }^{11}$ straw cigarette packs still contained banned descriptors like 'mild' and 'smooth'. Additionally, the vast majority of packs contained the words 'artesanal'/'artesanais'. While using 'artesanal', which implies handmade or handcrafted, is not surprising given their manufacturing process, this could reinforce the idea of a less harmful product as it implies a more 'natural' product due to its suggested simpler manufacturing process. Studies show that cigarette packs marketed as 'natural' by using terms such as 'additive free', 'organic' and 'premium quality tobacco' were deemed less harmful by adolescents. ${ }^{19} 20$ Therefore, 'artesanal' could potentially be banned as a misleading descriptor. Japan Tobacco International has announced plans for a Natural American Spirit biodegradable straw cigarette in Brazil, ${ }^{21}$ which could also increase misperceptions of harm among Brazilian youth. There may be value in considerations of policies that could prevent the introduction of potentially deceptive and harmful products.

Some of the imagery on the straw cigarette packaging resembles the iconic Marlboro cowboy and his symbolism of masculinity, independence and individualism. ${ }^{22}$ Packs with auto racing references also convey masculine symbolism. Previous research has shown that beer advertisement on Brazilian television used symbols of masculinity such as strength and virility. ${ }^{23}$ The high prevalence and prominence of masculine appeals on the packs could reinforce traditional gender norms related to the heterosexual white men in Brazil, which might include the adoption of unhealthy behaviours. ${ }^{24}$
The high prevalence of marketing appeals and misleading descriptors on straw cigarette packs in Brazil reinforce the need to adopt plain packaging for all tobacco products. Studies have shown that removing branding elements decreases smokers' favourable appraisal of packs, including among adolescents, which helps to reduce consumers' misperceptions of a product as less harmful. ${ }^{25-27}$ Plain packaging, in conjunction with the enactment of the additive ban, would help to reduce the appeal of tobacco products and prevent initiation among youth. While straw cigarettes are not common outside of Brazil, the type of marketing observed on the packs is not unique and reinforces the importance of applying policies to all tobacco products, with no exceptions. Moreover, straw cigarettes share similarities with other tobacco products that are marketed as natural and roll-your-own products; therefore, findings from this study can support other countries in assessing marketing strategies on the packaging of these types of tobacco products.

\section{What this paper adds}

- Cigarette packs in Brazil are branded, have elaborate designs and communicate the addition of flavours, increasing positive perceptions of tobacco. However, to the best of our knowledge, no studies have assessed branding on other tobacco products, such as straw cigarettes, in Brazil.

- Results of this study show that straw cigarette packs contain many marketing appeals, including flavours, masculine imagery and misleading descriptors. To reduce product appeal and initiation among youth, Brazil should adopt plain packaging and prioritise the enactment of the additive ban.

Acknowledgements We would like to acknowledge and thank ACT Health Promotion, our TPackSS partner in Brazil, for their expertise and for overseeing data collection (details on our website https://www.globaltobaccocontrol.org/tpackss/ about).

Contributors GG was the primary writer of the manuscript. All authors contributed to revising the manuscript critically for important intellectual content. All authors approved the final version of the manuscript.

Funding This work was supported with funding from Bloomberg Philanthropies Bloomberg Initiative to Reduce Tobacco Use (bloomberg.org) (47580).

Competing interests None declared.

\section{Patient consent for publication Not required.}

Provenance and peer review Not commissioned; externally peer reviewed.

Open access This is an open access article distributed in accordance with the Creative Commons Attribution Non Commercial (CC BY-NC 4.0) license, which permits others to distribute, remix, adapt, build upon this work non-commercially, and license their derivative works on different terms, provided the original work is properly cited, appropriate credit is given, any changes made indicated, and the use is non-commercial. See: http://creativecommons.org/licenses/by-nc/4.0/.

\section{ORCID iDs}

Graziele Grilo http://orcid.org/0000-0002-8377-4794

Kevin Welding http://orcid.org/0000-0002-1833-6691

André Salem Szklo http://orcid.org/0000-0003-1903-6188

Joanna E Cohen http://orcid.org/0000-0002-3869-3637

\section{REFERENCES}

1 World Health Organization. Tobacco: deadly in any form or disguise, 2006. Available: https://www.who.int/tobacco/communications/events/wntd/2006/Report_v8_ 4May06.pdf [Accessed 15 Jul 2021].

2 Thirupathi A, Scarparo S, Silva PL, et al. Physical exercise-mediated changes in redox profile contribute to muscle remodeling after passive hand-rolled cornhusk cigarette smoke exposure. Front Physiol 2020;11:590962.

3 Quissini GP, Camera FD, Roman SS. Avaliação da toxicidade do cigarro de palha artesanal e cigarro industrial sobre musculo diafragma de camundongos Swiss. Perspectiva 2018;42:65-71 https://www.uricer.edu.br/site/pdfs/perspectiva/1005_661.pdf 
4 Camara FDM, Pedroso GS, Roman SS, et al. Yerba mate (Ilex paraguariensis St. Hil.) extract inhibits hand-rolled cornhusk cigarette smoke-induced oxidative pulmonary damage. An Acad Bras Cienc 2020;92:e20191141.

5 Ministerio Publico do Estado de Minas Gerais. Operação "Porronca" investiga sonegação de mais de R\$100 milhões no setor de cigarros de palha, 2019. Available: https://www.mpmg.mp.br/comunicacao/noticias/operacao-investigasonegacao-de-mais-de-r-100-milhoes-no-setor-de-cigarros-de-palha.htm [Accessed 26 May 2021].

6 G1. Justiça manda apreender passaporte de empresário de Uberlândia alvo da Operação "Porronca", 2019. Available: https://g1.globo.com/mg/triangulo-mineiro/ noticia/2019/08/13/justica-manda-apreender-passaporte-de-empresario-deuberlandia-alvo-da-operacao-porronca.html [Accessed 26 May 2021].

7 Camargos D. Pandemia agrava exploração DOS enroladores de cigarro de palha em MG, 2020. Available: https://www1.folha.uol.com.br/cotidiano/2020/08/pandemiaagrava-exploracao-dos-enroladores-de-cigarro-de-palha-em-mg.shtml [Accessed 23 Mar 2021].

8 Kowalski LP. 0 cigarro de palha faz mal, afinal? 2017. Available: https://veja.abril.com. br/blog/letra-de-medico/o-cigarro-de-palha-faz-mal-afinal/ [Accessed 18 Mar 2021].

9 Alves E. 0 cigarro de palha virou hipster, mas já foi caipira, 2020. Available: http:// jornalismojunior.com.br/o-cigarro-de-palha-virou-hipster-mas-ja-foi-caipira/ [Accessed 18 Mar 2021].

10 Szklo AS. Monitoramento da epidemia de tabagismo no Brasil a partir dos resultados da Pesquisa Nacional de Saúde (PNS) 2019. [Presentation]. Divisão de Pesquisa Populacional. Instituto Nacional de Câncer José Alencar Gomes da Silva. Available: https://www.inca.gov.br/sites/ufu.sti.inca.local/files//media/document//resultados_ pesquisa_nacional_saude_2019.pdf [Accessed 17 Jun 2021].

11 Saúde Md̄a. Agência Nacional de Vigilância Sanitária. Resolução da diretoria colegiada - RDC no 195, de 14 de dezembro de 2017. Dispõe sobre embalagens e advertências sanitárias para produtos fumígenos derivados do tabaco, 2017. Available: https://www.saude.rj.gov.br/comum/code/MostrarArquivo.php?C= MTEwNTg\%2C [Accessed 22 Oct 2021].

12 Tobacco Pack Surveillance System (TPackSS). Marketing appeals on Brazilian cigarette packs [Fact Sheet]. Baltimore, MD: Johns Hopkins Bloomberg School of Public Health, 2021. https://globaltobaccocontrol.org/tpackss/sites/default/files/Brazil_f_and_a_FS_ 6_2020.pdf

13 White CM, Hammond D, Thrasher JF, et al. The potential impact of plain packaging of cigarette products among Brazilian young women: an experimental study. BMC Public Health 2012;12:1-10.

14 Islam F, Thrasher JF, Szklo A, et al. Cigarette flavors, package shape, and cigarette brand perceptions: an experiment among young Brazilian women. Rev Panam Salud Publica 2018;42:1-9.
15 Smith K, Washington C, Brown J, et al. The tobacco pack surveillance system: a protocol for assessing health warning compliance, design features, and appeals of tobacco packs sold in low- and middle-income countries. JMIR Public Health Surveill 2015;1:e4616:e8.

16 Tobacco Pack Surveillance System (TPackSS). Tobacco packaging features and marketing appeals codebook. Baltimore, MD: Johns Hopkins Bloomberg School of Public Health, 2017. https://www.globaltobaccocontrol.org/tpackss/sites/default/ files/Tobacco $\% 20$ Packaging $\% 2$ FFeatures $\% 20$ and $\% 2$ Marketing $\% 20$ Appeals $\%$ 20Codebook\%202017.pdf

17 Carpenter CM, Wayne GF, Pauly JL, et al. New cigarette brands with flavors that appeal to youth: tobacco marketing strategies. Health Aff 2005;24:1601-10.

18 Saúde Mda. Agência Nacional de Vigilância Sanitária. Resolução da diretoria colegiada - RDC no 14, de 15 março de 2012. Dispõe sobre os limites máximos de alcatrão, nicotina e monóxido de carbono nos cigarros e a restrição do uso de aditivos nos produtos fumígenos derivados do tabaco, e dá outras providências $2012 \mathrm{https}: / /$ bvsms.saude.gov.br/bvs/saudelegis/anvisa/2012/rdc0014_15_03_2012.pdf

19 Czoli CD, Hammond D. Cigarette packaging: youth perceptions of "natural" cigarettes, filter references, and contraband tobacco. J Adolesc Health 2014;54:33-9.

20 Kelly KJ, Manning K. The effects of natural cigarette claims on adolescents' brand related beliefs, attitudes, and intentions. J Health Commun 2014;19:1064-75.

21 Rural M. Primeiro palheiro totalmente biodegradável do Brasil sairá de Santa Cruz do Sul (RS), 2021. Available: https://www.minutorural.com.br/noticia/2173/primeiropalheiro-totalmente-biodegradavel-do-brasil-saira-de-santa-cruz-do-sul-rs- [Accessed 27 Apr 2021].

22 White C, Oliffe JL, Bottorff JL. From the physician to the Marlboro man: masculinity, health, and cigarette advertising in America, 1946-1964. Men and Masculinities 2012;15:526-47

23 de ORC, Cancela CD. Hierarquia em evidência: Um retrato da dominação hegemônica de masculinidade na propaganda de cerveja. Rev NUFEN 2012;4:37-48 http://pepsic bvsalud.org/scielo.php?script=sci_abstract\&pid=\$2175-25912012000200005\&lng= pt\&nrm=iso\&tlng=pt

24 Courtenay WH. Constructions of masculinity and their influence on men's well-being: a theory of gender and health. Soc Sci Med 2000;50:1385-401.

25 Wakefield MA, Germain D, Durkin SJ. How does increasingly plainer cigarette packaging influence adult smokers' perceptions about brand image? an experimental study. Tob Control 2008;17:416-21.

26 White V, Williams T, Wakefield M. Has the introduction of plain packaging with larger graphic health warnings changed adolescents' perceptions of cigarette packs and brands? Tob Control 2015;24:ii42-9.

27 Leas EC, Pierce JP, Dimofte CV, et al. Standardised cigarette packaging may reduce the implied safety of Natural American Spirit cigarettes. Tob Control 2018;27:e118-23. 